\title{
Cyclic AMP and Synaptic Activity-Dependent Phosphorylation of AMPA-Preferring Glutamate Receptors
}

\author{
Craig Blackstone, ${ }^{1, a}$ Timothy H. Murphy, ${ }^{1, b}$ Stephen J. Moss, ${ }^{1,3, c}$ Jay M. Baraban,, ${ }^{1,2}$ and Richard L. Huganir ${ }^{1,3}$ \\ ${ }^{1}$ Departments of Neuroscience, ${ }^{2}$ Psychiatry and Behavioral Sciences, and the ${ }^{3}$ Howard Hughes Medical Institute, \\ The Johns Hopkins University School of Medicine, Baltimore, Maryland 21205
}

Several studies have suggested that the function of glutamate receptor channels can be regulated by protein phosphorylation. Furthermore, a basal level of phosphorylation may be necessary to maintain receptor function. Little is known, however, about the phosphorylation state of glutamate receptor channels in neurons and how it is regulated by synaptic activity. In this study, we have investigated the phosphorylation of the AMPA-preferring glutamate receptor subunit GluR1 in cortical neurons in primary culture. These neurons elaborate extensive processes, form functional synapses, and exhibit spontaneous 4-8 sec bursts of synaptic activity every $15-20$ sec. In cultures in which this synaptic activity was suppressed by tetrodotoxin and MK-801, the GluR1 protein was phosphorylated on serine residues within a single tryptic phosphopeptide, as determined by phosphoamino acid analysis and phosphopeptide mapping. This same peptide was basally phosphorylated in recombinant GluR1 receptors transiently expressed in human embryonal kidney 293 cells. Treatment of these synaptically inactive cortical neurons with the adenylyl cyclase activator forskolin resulted in a robust Increase in phosphorylation on serine residues on a phosphopeptide distinct from the basally phosphorylated peptide. Again, this same phosphopeptide was observed in recombinant GluR1 receptors isolated from 293 cells coexpressing the catalytic subunit of cAMP-dependent protein kinase. Spontaneous synaptic activity in cultures of cortical neurons resulted in a consistent, rapid (within 10-30 sec) increase in phosphorylation on serine and threonine residues. Interestingly, these phosphopeptides were also phosphorylated when neurons from inactive cultures were stimulated with phorbol esters, which activate

\footnotetext{
Received Oct. 11, 1993; revised May 20, 1994; accepted June 2, 1994.

C.B. and T.H.M. contributed equally to this study. We are grateful to Drs. Michael Hollmann and Stephen Heinemann for the GluR $1_{\text {fop }}$ cDNA and to Dr. Michael D. Uhler for the cDNA of the catalytic subunit of PKA $(\mathrm{C} \alpha)$. This work was supported by an MSTP fellowship (C.B.), an NRSA fellowship (T.H.M.) USPHS Grants DA-00266 and MH-00926 (J.M.B.), and the Howard Hughes Medical Institute (R.L.H.).

Correspondence should be addressed to Dr. Richard L. Huganir, Department of Neuroscience, Howard Hughes Medical Institute, The Johns Hopkins University School of Medicine, 725 North Wolfe Street, PCTB 900, Baltimore, MD 21205-2185.

a Present address: Harvard-Longwood Neurology Program and Harvard Medical School, Boston, MA 02115.

b Present address: Kinsmen Laboratory for Neurological Research, Division of Neurological Sciences, Department of Psychiatry, University of British Columbia, Vancouver, BC V6T 1Z3, Canada.

Present address: IRC Institute for Molecular Cell Biology and Department of Pharmacology, University College, London WC1E 6BT, UK.

Copyright $(1994$ Society for Neuroscience $0270-6474 / 94 / 147585-09 \$ 05.00 / 0$
}

protein kinase $C$. These results indicate that AMPA receptors containing the GluR1 subunit may be regulated by extracellular signals working through the CAMP second messenger system as well as by synaptic activity, possibly acting through protein kinase $\mathrm{C}$. Such regulation by protein phosphorylation may be involved in short-term changes in synaptic efficacy thought to involve the functional modulation of AMPA receptors.

[Key words: glutamate, AMPA receptor, phosphorylation, CAMP, synaptic activity, long-term potentiation]

Glutamate receptors mediate excitatory neurotransmission in the CNS, playing critical roles during synaptogenesis, in mechanisms of synaptic plasticity such as long-term potentiation (LTP) and long-term depression (LTD), and in some neuropathological conditions (Ito et al., 1989; Siegelbaum and Kandel, 1991; Bliss and Collingridge, 1993; Shaw, 1993; Linden, 1994; Lipton and Rosenberg, 1994). These receptors can be divided into two broad categories: ionotropic receptors, oligomeric proteins that form ligand-gated ion channels; and metabotropic receptors, monomers that are coupled through guanine nucleotide-binding proteins to second messenger cascades. The ionotropic receptors have classically been divided into $\alpha$-amino-3-hydroxy-5-methyl-4-isoxazolepropionate (AMPA), kainate, and $N$-methyl-D-aspartate (NMDA) receptors based on their preferred agonists and electrophysiological properties (Monaghan et al., 1989). Over the past several years, molecular cloning studies have identified many subunits of the ionotropic receptors. These have been classified on the basis of sequence similarity and pharmacology as members of the AMPA (GluR 1-4), kainate (GluR 5-7, KAl, 2), and NMDA (NMDAR 1, 2A-D) receptor complexes (Gasic and Hollmann, 1992; Nakanishi, 1992; Sommer and Seeburg, 1992; Seeburg, 1993; Hollmann and Heinemann, 1994). Two additional subunits related in sequence ( $\delta 1$ and $\delta 2$ ) remain "orphan" receptors (Yamazaki et al., 1992; Lomeli et al., 1993). Further diversity is generated through alternative RNA splicing and posttranscriptional mRNA editing of many of these subunits (Sommer et al., 1990, 1991; Gallo et al., 1992; Sugihara et al., 1992; Seeburg, 1993). The predicted amino acid sequences derived from these cloning studies have permitted the generation of subunit-specific antibodies against these proteins, facilitating the study of such biochemical properties as receptor subunit composition and modification by protein phosphorylation and glycosylation (Rogers et al., 1991; Blackstone et al., 1992b; Wenthold et al., 1992, 1994; Moss et al., 1993; Raymond et al., 1993b; Roche et al., 1994; Sheng et al., 1994).

One posttranslational mechanism implicated in the long-term 
functional modulation of glutamatc receptors is phosphorylation by intracellular protein kinases (Blackstone et al., 1992c; Swope et al., 1992; Raymond et al., 1993b). Application of activators of cAMP-dependent protein kinase (PKA) as well as purified PKA has been shown to potentiate the function of AMPA/kainate receptors in cultured rat hippocampal neurons (Greengard et al., 1991; Wang et al., 1991) and teleost retinal horizontal cells (Liman et al., 1989). cAMP analogs, possibly working through PKA, increase the current and calcium influx through recombinant GluR1/GluR3 AMPA receptor channels expressed in Xenopus oocytes (Keller et al., 1992). Similarly, homomeric GluR6 kainate receptors transiently expressed in human embryonal kidney 293 cells are directly phosphorylated and potentiated by PKA (Raymond et al., 1993a; Wang et al., 1993). Another serine/threonine kinase, calcium/calmodulindependent protein kinase II (CaMKII), also enhances kainategated currents in cultured rat hippocampal neurons (McGladeMcCulloh et al., 1993). These reports strongly support a key role for direct protein phosphorylation of AMPA/kainate glutamate receptors in altering the excitability of neurons in the CNS.

Previous studies have shown that the recombinant GluR $1_{\text {flop }}$ (Hollmann et al., 1989) AMPA receptor protein expressed in 293 cells is a substrate for both tyrosine and serine/threonine kinases (Moss et al., 1993). In vitro phosphorylation studies using purified recombinant GluR1 (from Sf9 cells) as well as GluR1 isolated from rat brain synaptosomes and postsynaptic densities demonstrated phosphorylation by CaMKII and protein kinase C (PKC) but not by PKA (McGlade-McCulloh et al., 1993). In the present study, we sought to determine whether GluR1 can also be phosphorylated in cultured neurons by the activation of intracellular protein kinases through both synaptic activity and the extracellular application of membrane-permeable protein kinase activators. Using metabolic labeling, immunoprecipitation, and phosphoamino acid and phosphopeptide map analyses, we report the regulation of GluR 1 AMPA receptor phosphorylation by activators of PKA and PKC and compare these effects with those resulting from brief bursts of synaptic activity in cultured cortical neurons.

\section{Materials and Methods}

Materials. ${ }^{32} \mathrm{P}$-orthophosphate $(8500-9120 \mathrm{Ci} / \mathrm{mmol})$ was obtained from DuPont-New England Nuclear Research Products. TPCK-treated trypsin (EC 3.4.21.4; type XIII, from bovine pancreas), bovine serum albumin, ninhydrin, picrotoxin, and tetrodotoxin (TTX) were from Sigma. Aprotinin (Trasylol) was from Mobay Chemical. (+)-MK-801 was purchased from Research Biochemicals International. Okadaic acid was obtained from LC Services. Forskolin (Coleus forskohlii), microcystinLR, phorbol 12,13-diacetate (PDA), phorbol 12-myristate, 13-acetate (TPA), and 3-isobutyl-1-methylxanthine (IBMX) were obtained from Calbiochem. Anti-GluR1,-GluR2/3, and-GluR4 antibodies used in this study have been described previously (Blackstone et al., 1992a,b; Martin et al., 1993).

Primary cortical neuron cultures and metabolic labeling. Cultures were prepared from cerebral cortex dissected from embryonic day 17 Sprague-Dawley rats using a papain dissociation method as described previously (Murphy and Baraban, 1990; Murphy et al., 1992a). Cells were resuspended at $1.2 \times 10^{6} \mathrm{cells} / \mathrm{ml}$ in minimal essential medium (MEM) supplemented with $5.5 \mathrm{gm} /$ liter glucose, $2 \mathrm{~mm}$ glutamine, $10 \%$ fetal calf serum, $5 \%$ heat-inactivated horse serum, $50 \mathrm{U} / \mathrm{ml}$ penicillin, and $0.05 \mathrm{mg} / \mathrm{ml}$ streptomycin. They were then plated onto poly-L-lysine-coated 12-well dishes $\left(1 \mathrm{ml}\right.$ medium) and placed in a $\mathrm{CO}_{2}$-buffered $37^{\circ} \mathrm{C}$ incubator. Cells were fed as described previously (Murphy et al., 1992a). Cultures were allowed to mature for 3 weeks before use.

After 3 weeks in vitro, cultures were labeled for $4 \mathrm{hr}$ at $37^{\circ} \mathrm{C}$ in a phosphate-free Hank's balanced salt solution (HBSS) consisting of 137 $\mathrm{mm} \mathrm{NaCl}, 5.0 \mathrm{~mm} \mathrm{KCl}, 2.5 \mathrm{~mm} \mathrm{CaCl}_{2}, 1.0 \mathrm{~mm} \mathrm{MgSO}_{4}, 10 \mathrm{~mm}$ sodium HEPES, $1 \mathrm{~mm} \mathrm{NaHCO}$, and $22 \mathrm{~mm}$ glucose $(\mathrm{pH} 7.4)$ supplemented with $1-2 \mathrm{mCi} / \mathrm{ml}^{32} \mathrm{P}$ - orthophosphate. The labeling medium was then removed and replaced with phosphate-free HBSS containing picrotoxin $(10 \mu \mathrm{M})$ for synaptically active cultures, or picrotoxin $(10 \mu \mathrm{M})$, TTX (1 $\mu \mathrm{M})$, and MK-801 ( $3 \mu \mathrm{M})$ for synaptically inactive cultures. In the presence of the $G A B A_{A}$ receptor channel antagonist picrotoxin, virtually all cortical neurons within a culture exhibit highly synchronous spontaneous synaptic activity; a combination of TTX and MK-801 is used to block synaptic activity in these cultures (Murphy et al., 1992a, 1994). In experiments utilizing activators of intracellular protein kinases, the "synaptically inactive" culture solution was supplemented with either forskolin $(10 \mu \mathrm{M})$ and IBMX $(75 \mu \mathrm{M})$, or PDA (5 $\mu \mathrm{M})$ where indicated. Cultures were incubated with these solutions for $20 \mathrm{~min}$ at room temperature unless otherwise indicated.

We sought to determine the time course of GluR I phosphorylation after the initiation of synaptic activity. Since these cultures show prominent spontaneous firing and associated protein kinase activity (Murphy et al., 1994), we needed a method to suppress the endogenous synaptic activity that was readily reversible. Previous observations indicated that lowering extracellular calcium to $0.5 \mathrm{~mm}$ and raising magnesium to 2 mM suppressed the amplitude and duration of intracellular calcium transients, without affecting resting intracellular calcium levels (Murphy et al., 1992a, 1994). Cortical cultures were labeled with $1-2 \mathrm{mCi} / \mathrm{ml}$ ${ }^{32} \mathrm{P}$-orthophosphate for $4 \mathrm{hr}$ in a medium containing phosphate-free HBSS with low calcium ( $0.5 \mathrm{~mm}$ vs $2.25 \mathrm{~mm}$ ), high magnesium ( $2 \mathrm{~mm}$ vs $1 \mathrm{mM})$, and picrotoxin $(10 \mu \mathrm{M})$. Restoration of normal calcium and magnesium concentrations ( $2.25 \mathrm{~mm}$ and $1 \mathrm{~mm}$, respectively) by adding an equal volume of medium containing $4 \mathrm{~mm}$ calcium but no magnesium resulted in a rapid increase in the frequency and duration of synaptic bursts. In initial studies, we observed that treating cultures with the medium containing $0.5 \mathrm{~mm} \mathrm{CaCl}$ and $2 \mathrm{mM} \mathrm{MgSO}_{4}$ reduced GluR 1 phosphorylation to levels found in TTX-treated cultures maintained in the regular medium ( $2.25 \mathrm{~mm}$ calcium, $1 \mathrm{~mm}$ magnesium). To determine the time course of GluKl phosphorylation, we restored calcium and magnesium concentrations to normal levels for different amounts of time prior to harvesting the cultures.

All reactions were terminated by aspirating the medium and adding an ice-cold lysis buffer consisting of $50 \mathrm{~mm}$ sodium phosphate ( $\mathrm{pH} 7.5$ ), $1.0 \%$ Triton X-100, 0.5\% deoxycholate, $0.2 \%$ SDS, $50 \mathrm{~mm} \mathrm{NaF}, 10 \mathrm{~mm}$ sodium pyrophosphate, $5 \mathrm{~mm}$ EDTA, $5 \mathrm{~mm}$ EGTA, $1 \mathrm{~mm}$ sodium orthovanadate, $1 \mu \mathrm{M}$ okadaic acid, and $1 \mu \mathrm{M}$ microcystin-LR directly to the plates. The cells were scraped off of the plates, transferred to a microfuge tube, mixed by inversion, and then centrifuged $(15,000 \mathrm{rpm}$, $15 \mathrm{~min}, 4^{\circ} \mathrm{C}$ ) in a TOMY MTX-150 refrigerated microcentrifuge. The supernatant was transferred to another microfuge tube, and anti-GluR1 antiserum (final dilution 1:200) bound to protein A-Sepharose CL-4B (Pharmacia) that had been preblocked with $20 \mathrm{mg} / \mathrm{ml}$ bovine serum albumin was added. Following gentle agitation for $2 \mathrm{hr}$, the beads were washed sequentially with the following solutions: lysis buffer alone (twice); lysis buffer with $750 \mathrm{~mm} \mathrm{NaCl}$ (three times); $10 \mathrm{~mm}$ phosphate buffer (pH 7.5) with $0.1 \%$ Triton $X-100,50 \mathrm{~mm} \mathrm{NaF}$, and $5 \mathrm{~mm}$ EDTA (twice). Following removal of the final wash, SDS-PAGE sample buffer was added directly to the beads to elute antibody-bound GluR1.

Cell transfection and metabolic labeling. Human embryonal kidney 293 cells (ATCC CRL 1573) were maintained as described previously (Moss et al., 1993). Approximately 12-24 hr prior to transfection, cells were passaged and plated at a density of $10^{6}$ per plate $(10 \mathrm{~cm})$. Cells were then transfected by calcium phosphate coprecipitation, with each plate receiving $20 \mu \mathrm{g}$ of plasmid DNA. The cDNAs for GluR $1_{\text {fop }}$ (Hollmann et al., 1989) and the catalytic subunit of PKA (C $\alpha)$ (Uhler et al., 1986) were each subcloned into eukaryotic expression vectors under control of the cytomegalovirus promoter. For expression of GluR $1_{\text {flop }}$ alone, $20 \mu \mathrm{g}$ of the plasmid was used, while for cotransfection experiments $17 \mu \mathrm{g}$ of GluR $1_{\text {floo }}$ was cotransfected with $3 \mu \mathrm{g}$ of PKA C $\alpha$ DNA. Forty-eight hours after transfection, the cells were labeled in phosphatefree media (GIBCO) for $4 \mathrm{hr}$ with $2-4 \mathrm{mCi} / \mathrm{ml}{ }^{32} \mathrm{P}$-orthophosphate. Cells were then harvested and the GluR 1 protein was isolated by immunoprecipitation using anti-GluR 1 antibodies as described previously (Blackstone et al., 1992b; Moss et al., 1993).

Gel electrophoresis and immunoblotting. Immunoprecipitates were heated at $100^{\circ} \mathrm{C}$ for $2 \mathrm{~min}$, and then resolved by SDS-PAGE in $8.0 \%$ acrylamide gels. The gels were fixed in $25 \%$ methanol $/ 10 \%$ acetic acid and dried; ${ }^{32} \mathrm{P}$-labeled GluR 1 was revealed by autoradiography at $-70^{\circ} \mathrm{C}$ using Kodak XAR-5 film with a DuPont Cronex intensifying screen. 
For immunoblot analysis of AMPA receptor subunits expressed by cortical neurons in culture, total homogenates $(100 \mu \mathrm{g}$ protein/lane) were subjected to SDS-PAGE ( $8.0 \%$ gels). Proteins were then transferred to Immobilon P membrane (PVDF; Millipore) by electroblotting ( $30 \mathrm{~V}$, overnight), blocked for $1 \mathrm{hr}$ with $0.5 \%$ nonfat dry milk (Carnation)/ $0.1 \%$ Tween 20 in Tris-buffered saline (TBS: $50 \mathrm{~mm}$ Tris- $\mathrm{HCl}, \mathrm{pH} 7.4$, $150 \mathrm{~mm} \mathrm{NaCl}$ ), and probed with affinity-purified anti-GluR1,-GluR2/ 3 , or-GluR4 antibodies $(0.5 \mu \mathrm{g} / \mathrm{ml})$ for $1 \mathrm{hr}$ at room temperature. Following several washes with blocking buffer, horseradish peroxidaseconjugated donkey anti-rabbit secondary antiserum (1:5000; Amersham) was applied for $45 \mathrm{~min}$. The blots were washed several times with TBS, and specific immunodetection was revealed by enhanced chemiluminescence (ECL; Amersham).

Phosphopeptide mapping and phosphoamino acid analysis. Slices containing ${ }^{32} \mathrm{P}$-labeled GluR1 were excised from the gel, and the amount of radioactivity incorporated was determined by Cerenkov counting of the gel slice using a Beckman model LS 5801 liquid scintillation counter. Next, the GluR1 phosphoprotein was digested with trypsin $(300 \mu \mathrm{g} / \mathrm{ml}$, in $50 \mathrm{~mm}$ ammonium bicarbonate) overnight at $37^{\circ} \mathrm{C}$. The samples were dried in a Savant SpeedVac Concentrator, and then resuspended in 1 $\mathrm{ml} \mathrm{H}_{2} \mathrm{O}$ and dried again. The resulting tryptic fragments were finally resuspended in $10 \mu \mathrm{l}$ of $\mathrm{H}_{2} \mathrm{O}$ and spotted onto Kodak Chromagram thin-layer cellulose sheets along with the markers phenol red and basic fuchsin. Separation of the phosphopeptides in the first dimension was by electrophoresis $(500 \mathrm{~V})$ in acetic acid : pyridine: $\mathrm{H}_{2} \mathrm{O}(19: 1: 89 ; \mathrm{pH}$ 3.5 ) until the markers had migrated $6 \mathrm{~cm}$. The cellulose plates were air dried, and ascending chromatography was performed in the second dimension in pyridine : butanol:acetic acid: $\mathrm{H}_{2} \mathrm{O}(15: 10: 3: 12)$ for 16 $\mathrm{cm}$. Plates were air dried, and ${ }^{32} \mathrm{P}$-labeled phosphopeptides were revealed by autoradiography.

For phosphoamino acid analysis, tryptic peptides prepared as above were resuspended in $6 \mathrm{M} \mathrm{HCl}$, heated at $100^{\circ} \mathrm{C}$ for $1 \mathrm{hr}$, dried down in a SpeedVac, and finally resuspended in $10 \mu \mathrm{l}$ of $\mathrm{H}_{2} \mathrm{O}$. The samples were spotted onto thin-layer cellulose plates along with the marker phenol red and $10 \mu \mathrm{g}$ each of the phosphoamino acid standards phosphoserine, phosphothreonine, and phosphotyrosine. The phosphoamino acids were separated by electrophoresis $(500 \mathrm{~V})$, first in formic acid : acetic acid : $\mathrm{H}_{2} \mathrm{O}(1: 10: 89 ; \mathrm{pH} 1.9)$ for $5 \mathrm{~cm}$, and then in acetic acid: pyridine : $\mathrm{H}_{2} \mathrm{O}$ $(19: 1: 89, \mathrm{pH} 3.5)$ for another $8 \mathrm{~cm}$. The cellulose plate was stained with ninhydrin $(1.0 \%$, in acetone) to reveal the phosphoamino acid standards. ${ }^{32} \mathrm{P}$-labeled phosphoamino acids were revealed by autoradiography.

Protein content determination. Protein concentrations were determined by the bicinchoninic assay (Pierce) with bovine serum albumin as the standard.

\section{Results}

The expression of AMPA receptors in cortical neurons grown in culture for 3 weeks was evaluated using affinity-purified antibodies that specifically recognize the GluR1 or GluR4 subunits, and an antibody (denoted GluR2/3) that detects both GluR2 and GluR3 (Fig. 1). Neurons in primary culture showed a similar expression of AMPA receptor subunits to that of many cortical neurons in vivo (Petralia and Wenthold, 1992; Martin et al., 1993). By immunoblot analysis these antibodies detected proteins ranging from 102 to $108 \mathrm{kDa}$, sizes identical to those reported for recombinant and native receptor subunits in previous studies (Blackstone et al., 1992a,b; Martin et al., 1993). Expression of GluR 1-3 in neurons was relatively high in these cultures; however, little or no GluR4 immunoreactivity was detected. For each of these preparations, immunodetection was completely abolished by preadsorption of the antibodies to the synthetic peptide $(50 \mu \mathrm{g} / \mathrm{ml})$ to which they were raised (data not shown). Immunocytochemical studies revealed that virtually all neurons in the culture were immunostained by both the GluR 1 and GluR2/3 antibodies; some astrocytes showed GluR4 immunostaining (data not shown). Because of the individual subunit specificity of the GluR 1 antibodies and the relative abundance of this subunit in these neurons, we chose to evaluate phosphorylation of the GluR1 receptor subunit. By using met-
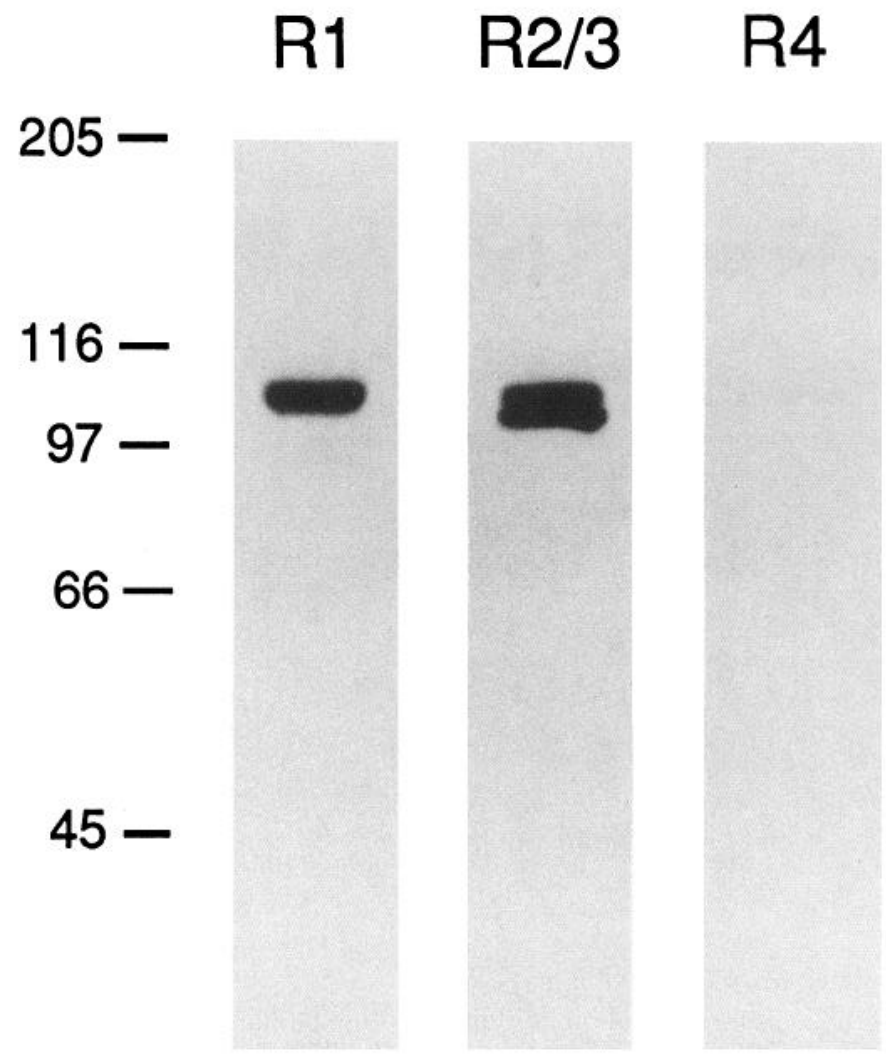

Figure 1. AMPA receptors in cultured cerebral cortical neurons. Total homogenates ( $100 \mu \mathrm{g}$ protein/lane) from cultured neurons ( 3 weeks in culture) prepared from cerebral cortices dissected from embryonic day 17 Sprague-Dawley rats were subjected to SDS-PAGE and immunoblotted with antibodies against GluR 1, GluR2/3, or GluR4 as indicated. The sizes of the molecular mass standards (in $\mathrm{kDa}$ ) are indicated to the left.

abolic labeling with ${ }^{32} \mathrm{P}$-orthophosphate and immunoprecipitation, we assessed the basal, activity-independent phosphorylation of GluR 1 and phosphorylation promoted by activators of PKA and PKC. Furthermore, we have compared the effects of these activators with those of endogenous synaptic stimulation.

Since previous studies have suggested that a basal level of protein phosphorylation may be important in the maintenance of receptor function (Wang et al., 1991), we first examined phosphorylation of the $106 \mathrm{kDa}$ GluR 1 protein after the spontaneous synaptic activity of the cultured cortical neurons was suppressed with TTX and MK-801 (i.e., basal phosphorylation). Immunoprecipitation of GluR 1 from ${ }^{32} \mathrm{P}$-orthophosphate-labeled cultures followed by SDS-PAGE analysis indicated that this receptor subunit was basally phosphorylated in the absence of synaptic activity (Fig. 2). Phosphopeptide map analysis indicated that this phosphorylation resided within a single tryptic phosphopeptide. To confirm that this phosphopeptide was indeed derived from GluR1 and to compare basal phosphorylation sites between native and recombinant receptors, the GluR 1 protein was transiently expressed in 293 cells. A similar analysis demonstrated that the basal phosphopeptide was also present in these recombinant receptors; in addition, several minor basal phosphopeptides were noted in the recombinant receptor protein (Fig. 2).

The modulation of the phosphorylation state of GluR1 was 
Figure 2. Activity-independent basal phosphorylation of GluR1. Left, GluR1 was isolated by immunoprecipitation from ${ }^{32} \mathrm{P}$ - orthophosphate-labeled transfected 293 cells or cultured cortical neurons in which the spontaneous synaptic activity of the cultures had been suppressed with TTX $(1 \mu \mathrm{M})$ and MK$801(3 \mu \mathrm{M})$. The immunoprecipitates were resolved by SDS-PAGE, and ${ }^{32} \mathrm{P}$ labeled GluR1 was visualized using autoradiography. The sizes of molecular mass standards (in $\mathrm{kDa}$ ) are indicated. Right, Gel slices containing GluR 1 were excised and digested with trypsin, and the resulting phosphopeptides were separated by thin-layer chromatography on cellulose layers in two dimensions as shown. The origins are identified with circles. The major basal phosphopeptide common to both recombinant and neuronal GluR1 is indicated (arrowheads).

then studied in cultured neurons prelabelled with ${ }^{32} \mathrm{P}$-orthophosphate. Stimulation of synaptically inactive cultures with the adenylyl cyclase activator forskolin and the phosphodiesterase inhibitor IBMX induced a $60 \% \pm 6 \%(n=3)$ increase above basal levels of ${ }^{32} \mathrm{P}_{\mathrm{i}}$ incorporated into GluR1, as determined by Cerenkov counting of the excised GluR1-containing gel slice. Stimulation of the inactive cultures with the phorbol ester PDA resulted in an increase in phosphorylation of $44 \% \pm$ $19 \%(n=3)$. Finally, spontaneous synaptic activity resulted in a $38 \% \pm 9 \%(n=7)$ increase in phosphorylation compared to synaptically inactive neurons.

As these receptors are basally phosphorylated, we sought to determine whether the observed modulation of these receptors involved the same or different residues. The amino acid residues phosphorylated were evaluated by phosphoamino acid analysis (Fig. 3). The basal phosphorylation was exclusively on serine residues, consistent with previous findings for the recombinant GluR1 receptor (Moss et al., 1993). The increase in phosphorylation in response to forskolin and IBMX was overwhelmingly on serine residues, although slight increases in threonine and tyrosine phosphorylation were noted as well. Spontaneous synaptic activity or treatment of inactive cultures with the phorbol ester PDA showed increases in serine and threonine phosphorylation (Fig. 3). Individual sites of phosphorylation were revealed by two-dimensional phosphopeptide mapping of tryptic GluR1 peptides (Fig. $4 A-D$ ). Increases in response to forskolin treatment were confined to a tight cluster of slowly migrating peptides (compare Fig. 4A,B). Smaller but consistent increases were observed with phorbol ester treatment, which resulted in several less intense, scattered phosphopeptides (compare Fig. $4 A, C$ ). Interestingly, spontaneous synaptic activity of the neurons (Fig. $4 D$ ) resulted in a phosphopeptide map pattern almost identical to that seen with phorbol ester stimulation. These results are summarized in Figure $4 F$ and in Table 1 . Analysis of recombinant GluR1 from 293 cells activated with forskolin (50 $\mu \mathrm{M})$, IBMX (75 $\mu \mathrm{M})$, and the phorbol ester TPA (100 nM) resulted in a phosphorylation pattern (Fig. $4 E$ ) similar to that seen in neurons, accounting for all phosphopeptides observed in GluR 1 isolated from the neurons. The minor basal phosphopeptides from unstimulated 293 cells (Fig. 2) resemble those from neurons that appear upon stimulation with phorbol ester (Fig. $4 \mathrm{C}$ ),
Neurons

293 Cells
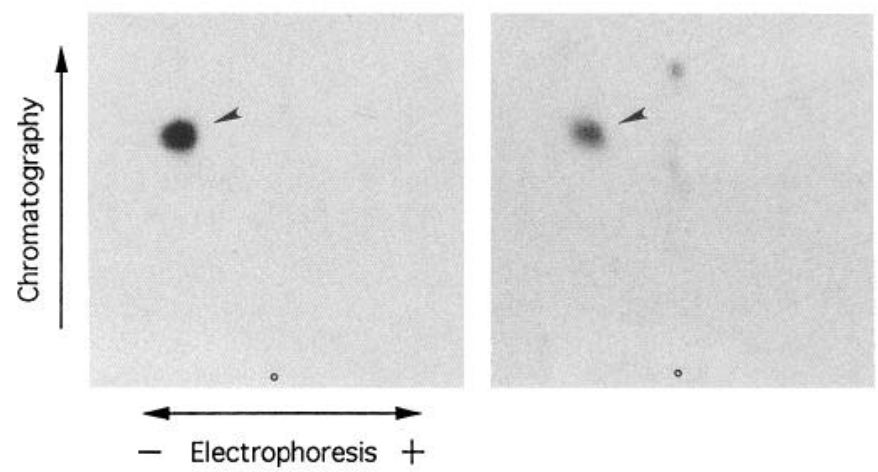

indicating that this additional phosphorylation of recombinant GluR1 may be due to basal PKC activity in the 293 cells. In some cases, such as phosphopeptide 1 in Figure $4 C-E$, it is possible that several phosphopeptides with similar migrations may appear as one phosphopeptide. However, when the electrophoresis was conducted until the markers had migrated $8 \mathrm{~cm}$ in the first dimension (instead of $6 \mathrm{~cm}$ ) no additional distinctions were evident (data not shown).

Given the large increase in phosphorylation at a site distinct from the basal site in response to forskolin treatment in neurons, yet the relatively small increase noted in GluR 1-transfected 293 cells in previous studies (Moss et al., 1993), we examined the ability of heterologously expressed PKA to direct phosphorylation of recombinant GluR 1 (Fig. 5). Cells coexpressing GluR 1 and PKA $\mathrm{C} \alpha$ showed a robust ( $>10$-fold) increase in GluR1 phosphorylation above basal levels. In Figure 5, the $99 \mathrm{kDa}$ phosphoprotein represents an unglycosylated precursor form of GluR1 (Blackstone et al., 1992b), while the more intensely labeled $106 \mathrm{kDa}$ phosphoprotein represents mature glycosylated GluR1. Both signals were completely abolished by preadsorption of the antibodies with an excess $(50 \mu \mathrm{g} / \mathrm{ml})$ of synthetic peptide prior to immunoprecipitation. Two-dimensional phosphopeptide map analysis revealed that this increased GluR1 phosphorylation in response to PKA C $\alpha$ cotransfection was confined to the same phosphopeptide as in the forskolin-stimulated neurons. Tryptic digestion generated either tight clusters of several distinct phosphopeptides (as in native receptor PKA-dependent phosphorylation shown in Fig. 5) or a single major phosphopeptide (as in recombinant receptor PKA-dependent phosphorylation shown in Fig. 5). However, both patterns were seen with recombinant as well as native receptors over several different experiments, suggesting that the additional phosphopeptides reflect incomplete digestion or additional phosphorylation events within the same tryptic fragment. This PKA phosphopeptide cluster was much more highly phosphorylated with respect to the basal phosphopeptide in recombinant GluR 1 from 293 cells relative to that observed in GluR 1 isolated from cultured cortical neurons (Fig. 5), most likely due to the lower stoichiometry of basal phosphorylation in the recombinant protein.

We examined the time course of GluR 1 phosphorylation in 

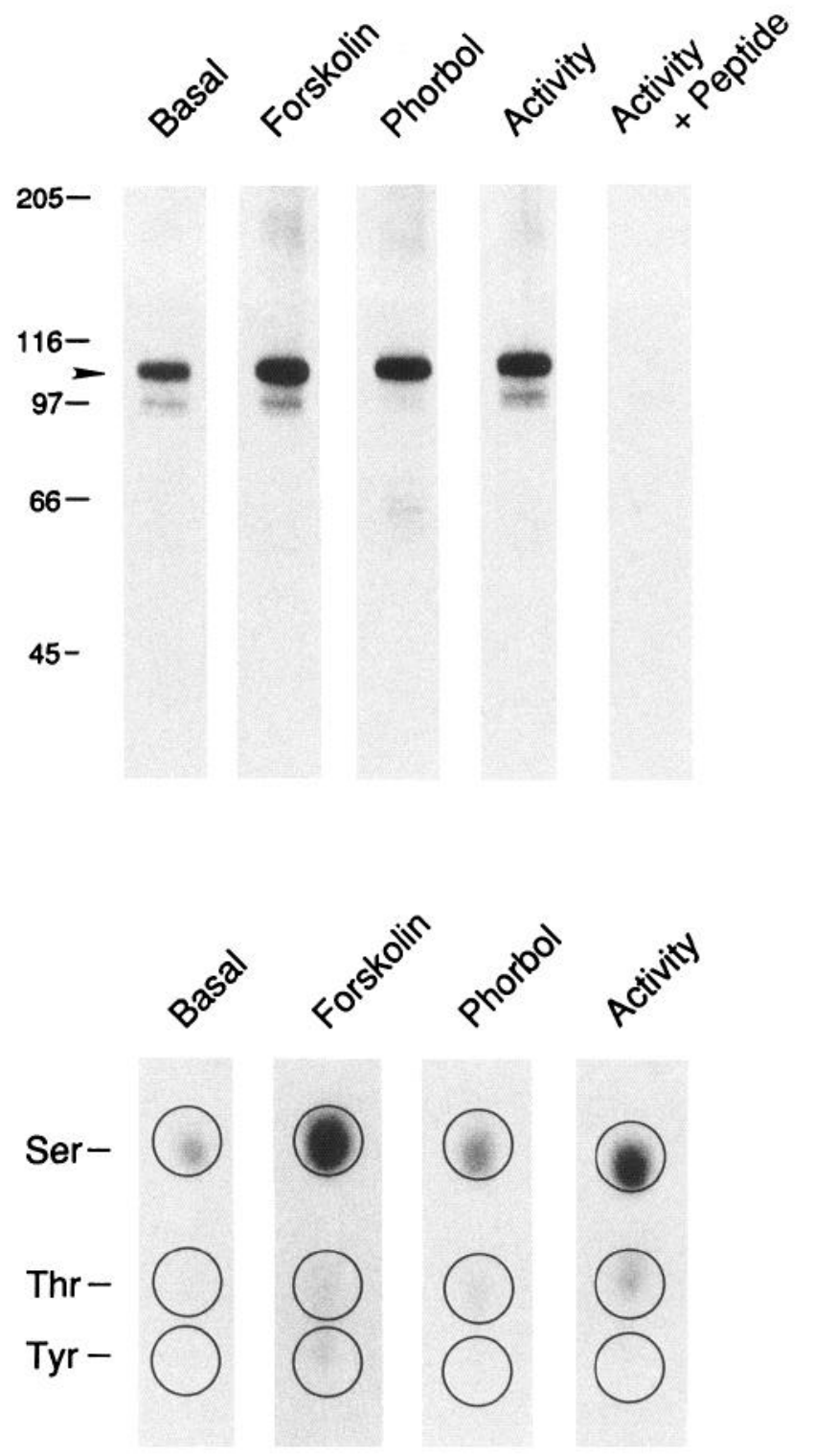

Figure 3. Second messenger and synaptic activity-dependent phosphorylation of GluR1 in cortical neurons. Top, Neuronal cultures in which the spontaneous synaptic activity was suppressed with TTX and MK-801 were prelabeled with ${ }^{32} \mathrm{P}$ - orthophosphate and then treated with either forskolin and IBMX or phorbol ester (PDA) for $20 \mathrm{~min}$. Where indicated, the endogenous synaptic activity of the cultures was not blocked, and the incubation was continued for $20 \mathrm{~min}$. GluR1 was isolated by immunoprecipitation, resolved by SDS-PAGE, and visualized by autoradiography. Where indicated, immunoprecipitation from synaptically active cultures was conducted using antibodies which had been preadsorbed with an excess of synthetic peptide. Sizes of molecular mass standards are shown in kilodaltons. The GluR1 phosphoprotein is identified with an arrowhead. Bottom, The GluR 1-containing gel slices were excised, and GluR1 was digested with trypsin and hydrolyzed with $6 \mathrm{M} \mathrm{HCl}$. The resulting phosphoamino acids were then separated by electrophoresis as described in Materials and Methods. The migrations of ninhydrin-stained phosphoserine (Ser), phosphothreonine (Thr), and phosphotyrosine (Tyr) phosphoamino acid standards are indicated (circles). Forskolin-stimulated Thr and Tyr as well as phorbol ester-stimulated Thr phosphorylation were revealed more clearly on longer exposures.

\begin{tabular}{|c|c|c|c|c|}
\hline \multirow[b]{2}{*}{$\begin{array}{l}\text { Phospho- } \\
\text { peptide }\end{array}$} & \multirow[b]{2}{*}{ Basal } & \multicolumn{3}{|l|}{ Treatment } \\
\hline & & Forskolin & $\begin{array}{l}\text { Phorbol } \\
\text { ester }\end{array}$ & $\begin{array}{l}\text { Synaptic } \\
\text { activity }\end{array}$ \\
\hline 1 & ++++ & ++++ & ++++ & ++++ \\
\hline 2 & - & + & ++ & ++ \\
\hline 3 & - & + & + & ++ \\
\hline 4 & - & - & ++ & ++ \\
\hline 5 & $-1+$ & ++++ & ++ & ++ \\
\hline 6 & - & - & ++ & +++ \\
\hline
\end{tabular}

Phosphopeptide numbering is derived from Figure $4 F$. Signal intensity: -, undetectable; + , low; ++ , moderate; +++ , high; ++++ , intense.

response to strong synaptic burst stimulation. Cortical neurons were prelabeled with ${ }^{32} \mathrm{P}$-orthophosphate, and the amplitude and duration of synaptic bursts were suppressed by lowering the extracellular $\mathrm{CaCl}_{2}$ to $0.5 \mathrm{~mm}$ and increasing $\mathrm{MgSO}_{4}$ to $2 \mathrm{~mm}$ as described in Materials and Methods. Extracellular calcium was then restored to $2.25 \mathrm{~mm}$ for times ranging from $10 \mathrm{sec}$ to $20 \mathrm{~min}$ (at room temperature) before terminating the reaction with ice-cold lysis buffer. The GluR 1 protein was then immunoprecipitated and resolved by SDS-PAGE. Gel slices containing GluR 1 were excised, and the radioactivity incorporated was determined by Cerenkov counting. Synaptic bursting resulted in a rapid increase in phosphorylation of GluR 1 , with $>50 \%$ of the increase in phosphorylation occurring within the first 30 sec. By $10 \mathrm{~min}$, the increase in phosphorylation had plateaued. Phosphopeptide map analysis of tryptic digests of GluR1 consistently revealed that these activity-dependent increases in phosphorylation were on the same tryptic peptides as shown previously in Figure $4 D$ (data not shown). Restoration of calcium levels for up to $10 \mathrm{~min}$ in the presence of TTX did not lead to increased GluR1 phosphorylation (data not shown), suggesting that activation is associated with augmented synaptic activity and not the solution changes themselves.

\section{Discussion}

In this study, we have evaluated the phosphorylation state of the GluR1 AMPA receptor subunit in cultured cortical neurons in response to various stimuli. These included the spontaneous synaptic activity of the cultures as well as membrane-permeable activators of intracellular second messenger systems and protein kinases. In neurons in which the spontaneous synaptic activity was suppressed (inactive neurons), the GluR1 protein (most likely including both flip and flop alternative splice forms) was phosphorylated on serine residues within a single tryptic phosphopeptide. Previous electrophysiological studies in cultured hippocampal neurons reported a "rundown" of kainate-evoked currents when electrode solutions without ATP were used that was likely due, at least in part, to the decreased ability of the neurons to maintain intracellular phosphorylation (Wang et al., 1991). The strong basal phosphorylation we observe would be consistent with these observations. Furthermore, the ability to observe phosphorylation of this same site in recombinant GluR 1 receptors should make it possible to identify the site, remove it by site-specific mutagenesis, and note any direct functional changes that result. Identification of the residue may also provide clues as to the identity of the protein kinase responsible for this basal phosphorylation. 

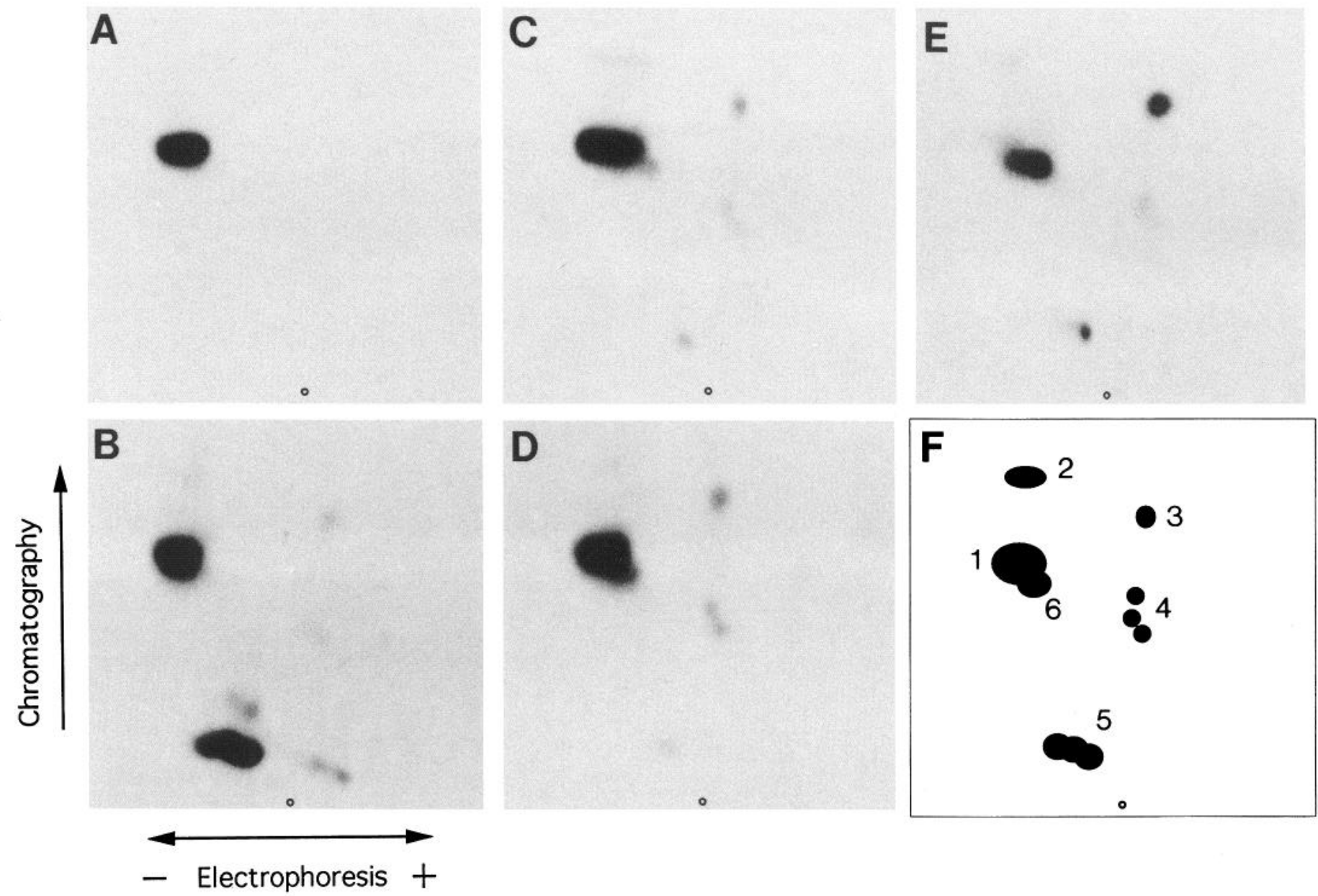

Figure 4. Phosphopeptide map analysis of GluR1. $A-D$, Cortical neurons were prelabeled with ${ }^{32} \mathrm{P}$-orthophosphate and treated as described. The GluR1 protein was immunoprecipitated and resolved by SDS-PAGE. Gel pieces were excised and digested with trypsin. The resulting tryptic GluR 1 fragments were separated in two dimensions by thin-layer chromatography, and ${ }^{32}$ P-labeled GluR 1 phosphopeptides were revealed by autoradiography. The origins are indicated (circles). $A$, Synaptically inactive cultures (basal). $B$, Synaptically inactive cultures + forskolin, IBMX. $C$, Synaptically inactive cultures + phorbol ester (PDA). $D$, Synaptically active cultures. $E$, For confirmation that all of these phosphopeptides in $A-D$ were derived from the GluR1 receptor, GluR 1-transfected 293 cells were prelabeled with ${ }^{32} \mathrm{P}$-orthophosphate as above and then treated with phorbol ester (TPA), forskolin, and IBMX. Immunoprecipitation, SDS-PAGE, tryptic digestion, and phosphopeptide mapping were performed as in $A-D . F$, Schematic diagram showing the major phosphopeptides present in $A-E$.

In addition to the strong phosphorylation at this location, a robust increase in phosphorylation on another phosphopeptide was observed in response to forskolin stimulation, also on serine residues. The same phosphopeptide was detected in receptor isolated from 293 cells cotransfected with the catalytic subunit of PKA, strongly supporting a role for PKA-mediated phosphorylation of GluR 1 in neurons. In fact, in hippocampal neurons kainate-gated currents mediated by AMPA receptors are enhanced by cAMP analogs and PKA, and they are diminished by inhibitors of PKA (Greengard et al., 1991; Wang et al., 1991). In white perch retinal horizontal cells, a similar increase in the kainate-evoked current was observed (Liman et al., 1989). Moreover, cAMP analogs also potentiated the current and calcium influx through recombinant AMPA receptors consisting of GluR1 and GluR3 subunits expressed in Xenopus oocytes (Keller et al., 1992). Interestingly, there is no ideal consensus site for PKA phosphorylation (i.e.,-Arg-Arg-X-Ser-) anywhere in the GluR1 protein (Hollmann et al., 1989), and in vitro studies have failed to show PKA phosphorylation of GluR1 (McGladeMcCulloh et al., 1993). It may be that phosphorylation of GluR1 is at a site not conforming to the ideal consensus sequence and that native conformation, subunit composition, or accessory proteins are important for phosphorylation, or alternatively that the phosphorylation is not direct but occurs through a kinase cascade. In the latter case, the same cascade would also have to be operative in kidney epithelial cells (i.e., 293 cells). The ability to phosphorylate the recombinant receptor to very high levels by cotransfection with PKA C $\alpha$ should make these issues amenable to study by identification of the site and its replacement by site-directed mutagenesis.

Another significant finding of this study is the increase in phosphorylation observed in response to brief bursts of synaptic activity. As determined by phosphopeptide map analysis, these sites are essentially the same as those phosphorylated in response to phorbol ester stimulation, suggesting the involvement of PKC either directly or as part of a kinase cascade. In fact, synaptic activity in these cultures has previously been shown to activate the phosphoinositide second messenger system (Murphy et al., 1992b), which results in the stimulation of PKC; however, this synaptic activity also results in a rapid increase 


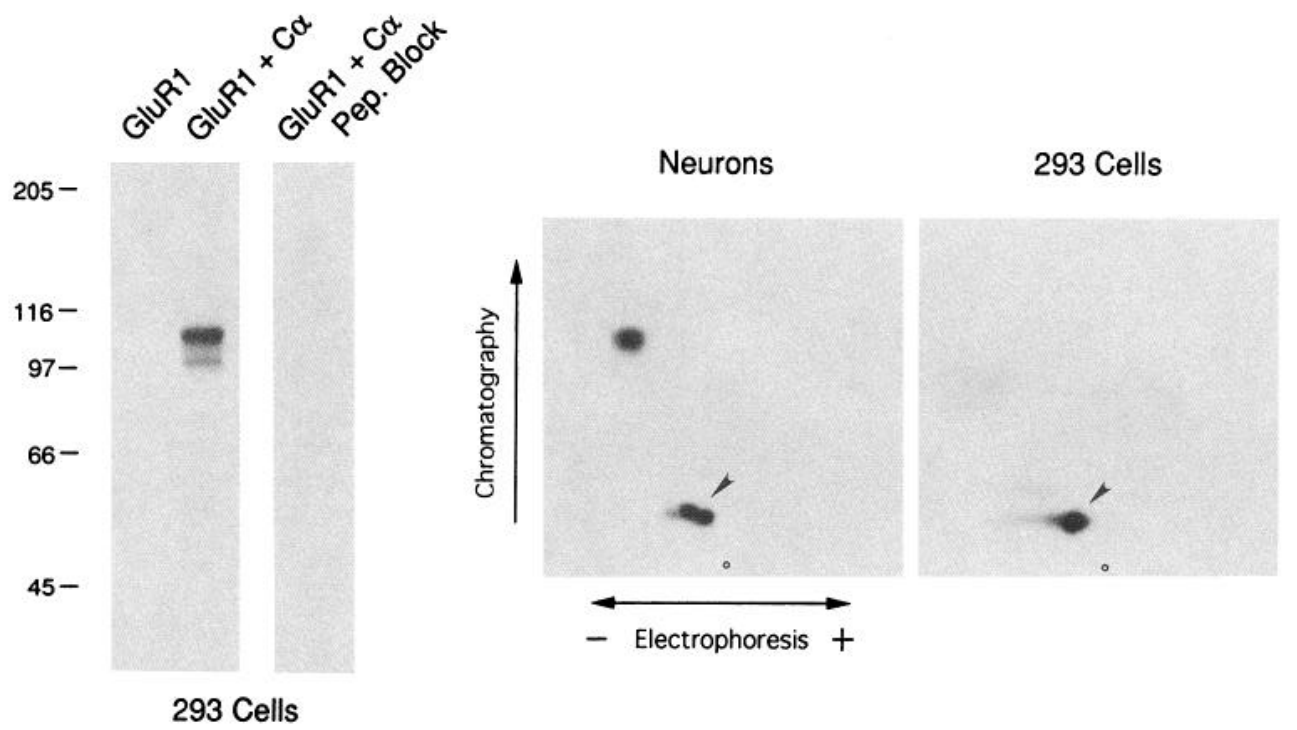

Figure 5. PKA-mediated phosphorylation of GluR1 in transfected 293 cells. Left, Human embryonal kidney 293 cells were transfected with GluR 1 or cotransfected with GluR1 and PKA C $\alpha$ and prelabeled with ${ }^{32} \mathrm{P}$-orthophosphate. The GluR1 protein was isolated by immunoprecipitation using anti-GluR1 antipeptide antibodies and resolved by SDS-PAGE. Basal phosphorylation in the GluR1 lane was revealed at longer exposures. Where indicated, the antibodies were first preadsorbed with an excess of synthetic peptide. Sizes of molecular mass standards (in kilodaltons) are indicated. Right, Gel slices containing GluR1 that had been isolated from 293 cells cotransfected with PKA C $\alpha$ were excised and digested with trypsin. The resulting phosphopeptides were separated in two dimensions on thin-layer cellulose plates and visualized by autoradiography. The origin is indicated circle). A phosphopeptide map of trypsin-digested GluR1 isolated from cultured cortical neurons which had been stimulated with the adenylyl cyclase activator forskolin (as in Fig. $4 B$ ) is included for comparison. The PKA-dependent phosphorylation site common to both neuronal and recombinant GluR1 is indicated (arrowheads). The basal phosphorylation site (as in Fig. 2) is clearly seen in neuronal GluR1 at this exposure, but is evident in recombinant GluR1 only on longer exposures.

in the activity of another kinase, CaMKII. The increase in GluR1 phosphorylation in response to synaptic activity was very rapid, with $>50 \%$ of the stimulation occurring within the first 30 sec. In these cultures, $90 \%$ of maximal CaMKII activity occurs within the first $10 \mathrm{sec}$ of synaptic activity (Murphy et al., 1994). Thus, it remains possible that CaMKII is involved in this phosphorylation. Supporting this notion are previous studies showing that CaMKII phosphorylates GluR1 in vitro, and that activated CaMKII enhances kainate-gated currents in cultured hippocampal neurons (McGlade-McCulloh et al., 1993). Preliminary studies suggest that the activity-dependent phosphorylation in cortical neurons lasts for many minutes after the activity is terminated; changes are diminished but still evident after $10 \mathrm{~min}$ of inactivity following $20 \mathrm{~min}$ of activity (C. Blackstone, T. H. Murphy, J. M. Baraban, and R. L. Huganir, unpublished observations). Thus, this phosphorylation may be involved in some mechanisms of short-term changes in synaptic efficacy (Kullmann et al., 1992) that may involve modulation of AMPA receptor sensitivity. Interestingly, $30 \mathrm{sec}$ of synaptic bursting, which leads to an increase in GluR1 phosphorylation, also results in an increase in network synaptic activity which declines over a $20 \mathrm{~min}$ period (T. H. Murphy and J. M. Baraban, unpublished observations).

One possible concern is that the stoichiometry of the activitydependent and phorbol ester-stimulated phosphorylation appears low, particularly relative to basal and PKA-mediated phosphorylation. Though the changes may in fact be smaller, it is also possible that the result is deceiving. Many immunocytochemical studies evaluating rat brain sections and neurons in culture have demonstrated that although these AMPA receptors are most enriched in spines and postsynaptic densities, there are extensive nonsynaptic intracellular pools of receptor as well
(Blackstone et al., 1992b; Petralia and Wenthold, 1992; Craig et al., 1993; Martin et al., 1993). It may be that most receptors are accessible to the protein kinase responsible for basal phosphorylation as well as to PKA, but that synaptic activity-dependent kinase activation results in phosphorylation of only synaptic receptors. Thus the relative stoichiometry of the activity-dependent phosphorylation may appear artificially low on phosphopeptide maps. Even so, the relatively low stoichiometry of phorbol ester-stimulated phosphorylation is not likely to be due to spatial restriction of PKC activation. It is possible, however, that PKC phosphorylation is relatively slow and incomplete or that PKC is part of a kinase cascade involving a more spatially restricted kinase. Identification of the kinase(s) involved should help to clarify this issue.

In future studies, it will be interesting to examine other AMPA receptor subunits (GluR2-4 and splice variants) to determine whether there is any subunit variation in phosphorylation. Differential regulation by protein phosphorylation has been demonstrated for $\mathrm{GABA}_{\mathrm{A}}$ receptors, nicotinic acetylcholine receptors, and glycine receptors through protein kinases acting at sites in the proposed major intracellular loop between putative transmembrane domains III and IV (Swope et al., 1992). Unlike subunits from these other receptor families the proposed major intracellular loops are nearly identical among GluR1-4 (Keinänen et al., 1990), and it might be expected that there may not be differential phosphorylation among the AMPA receptor subunits. However, recent studies with the NMDA receptor subunit NMDAR1 suggest that, contrary to proposed topology models, the C-terminal domain is in fact intracellular (Tingley et al., 1993). Immunocytochemical findings using antibodies directed against specific regions of AMPA receptor subunits are also consistent with an intracellular location of this domain for 
GluR 1-4 (Petralia and Wenthold, 1992; Craig et al., 1993; Martin et al., 1993; Molnár et al., 1993). As this region is quite divergent among GluR $1-4$, the prospects for differential regulation by protein phosphorylation may be greater than previously suspected. Studies aimed at identifying specific residues at which receptor phosphorylation occurs and examining the functional significance of these modifications by site-directed mutagenesis techniques in heterologous expression systems may help to clarify molecular mechanisms underlying synaptic plasticity.

\section{References}

Blackstone CD, Levey AI, Martin LJ, Price DL, Huganir RL (1992a) Immunological detection of glutamate receptor subtypes in human central nervous system. Ann Neurol 31:680-683.

Blackstone CD, Moss SJ, Martin LJ, Levey AI, Price DL, Huganir RL (1992b) Biochemical characterization and localization of a non- $N$ methyl-D-aspartate glutamate receptor in rat brain. J Neurochem 58: $1118-1126$.

Blackstone CD, Raymond L, Moss SJ, Huganir RL (1992c) Regulation of non-NMDA glutamate receptors by protein phosphorylation. In: Fidia Research Foundation symposium series, Vol 9, Excitatory amino acids (Simon RP, ed), pp 15-20. New York: Thieme.

Bliss TVP, Collingridge GL (1993) Synaptic model of memory: longterm potentiation in the hippocampus. Nature 361:31-39.

Craig AM, Blackstone CD, Huganir RL, Banker G (1993) The distribution of glutamate receptors in cultured rat hippocampal neurons: postsynaptic clustering of AMPA-selective subunits. Neuron 10:10551068 .

Gallo V, Upson LM, Hayes WP, Vyklicky L Jr, Winters CA, Buonanno A (1992) Molecular cloning and developmental analysis of a new glutamate receptor isoform in cerebellum. J Neurosci 12:1010-1023.

Gasic GP, Hollmann M (1992) Molecular neurobiology of glutamate receptors. Annu Rev Physiol 54:507-536.

Greengard P, Jen J, Nairn AC, Stevens CF (1991) Enhancement of the glutamate response by cAMP-dependent protein kinase in hippocampal neurons. Science 253:1135-1138.

Hollmann M, Heinemann S (1994) Cloned glutamate receptors. Annu Rev Neurosci 17:31-108.

Hollmann M, O'Shea-Greenfield A, Rogers SW, Heinemann S (1989) Cloning by functional expression of a member of the glutamate receptor family. Nature 342:643-648.

Ito M (1989) Long-term depression. Annu Rev Neurosci 12:85-102.

Keller BU, Hollmann M, Heinemann S, Konnerth A (1992) Calcium influx through subunits GluR1/GluR3 of kainate/AMPA receptor channels is regulated by cAMP dependent protein kinase. EMBO J 11:891-896.

Kullmann DM, Perkel DJ, Manabe T, Nicoll RA (1992) $\mathrm{Ca}^{2+}$ entry via postsynaptic voltage-sensitive $\mathrm{Ca}^{2+}$ channels can transiently potentiate excitatory transmission in the hippocampus. Neuron 9:11751183.

Liman ER, Knapp AG, Dowling JE (1989) Enhancement of kainategated currents in retinal horizontal cells by cyclic AMP-dependent protein kinase. Brain Res 481:399-402.

Linden DJ (1994) Long-term synaptic depression in the mammalian brain. Neuron 12:457-472.

Lipton SA, Rosenberg PA (1994) Mechanisms of disease: excitatory amino acids as a final common pathway for neurologic disorders. $\mathrm{N}$ Engl J Med 330:613-622.

Lomeli H, Sprengel R, Laurie DJ, Köhr G, Herb A, Seeburg PH, Wisden W (1993) The rat delta-1 and delta-2 subunits extend the excitatory amino acid receptor family. FEBS Lett 315:318-322.

Martin LJ, Blackstone CD, Levey AI, Huganir RL, Price DL (1993) AMPA glutamate receptor subunits are differentially distributed in rat brain. Neuroscience 53:327-358.

McGlade-McCulloh E, Yamamoto H, Tan S-E, Brickey DA, Soderling TR (1993) Phosphorylation and regulation of glutamate receptors by calcium/calmodulin-dependent protein kinase II. Nature 362:640642.

Molnár E, Baude A, Richmond SA, Patel PB, Somogyi P, McIlhinney RAJ (1993) Biochemical and immunocytochemical characterization of antipeptide antibodies to a cloned GluR 1 glutamate receptor subunit: cellular and subcellular distribution in the rat forebrain. Neuroscience 53:307-326.

Monaghan DT, Bridges RJ, Cotman CW (1989) The excitatory amino acid receptors: their classes, pharmacology, and distinct properties in the function of the central nervous system. Annu Rev Pharmacol Toxicol 29:365-402.

Moss SJ, Blackstone CD, Huganir RL (1993) Phosphorylation of recombinant non-NMDA glutamate receptors on serine and tyrosine residues. Neurochem Res 18:105-110.

Murphy TH, Baraban JM (1990) Glutamate toxicity in immature cortical neurons precedes development of glutamate receptor currents. Dev Brain Res 57:146-150.

Murphy TH, Blatter LA, Wier WG, Baraban JM (1992a) Spontaneous synchronous synaptic calcium transients in cultured cortical neurons. J Neurosci 12:4834-4845.

Murphy TH, Wright DD, Baraban JM (1992b) Phosphoinositide turnover associated with synaptic transmission. J Neurochem 59:23362339.

Murphy TH, Blatter LA, Bhat RV, Fiore RS, Wier G, Baraban JM (1994) Differential regulation of calcium calmodulin dependent protein kinase II and p42 MAP kinase activity by synaptic transmission. J Neurosci 14:1320-1331.

Nakanishi S (1992) Molecular diversity of glutamate receptors and implications for brain function. Science 258:597-603.

Petralia RS, Wenthold RJ (1992) Light and electron immunocytochemical localization of $\Lambda$ MPA-selective glutamate receptors in the rat brain. J Comp Neurol 318:329-354.

Raymond LA, Blackstone CD, Huganir RL (1993a) Phosphorylation and modulation of recombinant GluR6 glutamate receptors by cAMP. dependent protein kinase. Nature 361:637-641.

Raymond LA, Blackstone CD, Huganir RL (1993b) Phosphorylation of amino acid neurotransmitter receptors in synaptic plasticity. Trends Neurosci 16:147-153.

Roche KW, Raymond LA, Blackstone C, Huganir RL (1994) Transmembrane topology of the glutamate receptor subunit GluR6. J Biol Chem 269:11679-11682.

Rogers SW, Hughes TF, Hollmann M, Gasic GP, Deneris FS, Heinemann S (1991) The characterization and localization of the glutamate receptor subunit GluR1 in the rat brain. J Neurosci 11:27132724.

Seeburg PH (1993) The TINS/TiPS lecture: the molecular biology of mammalian glutamate receptor channels. Trends Neurosci 16:359365.

Shaw PJ (1993) Excitatory amino acid receptors, excitotoxicity, and the human nervous system. Curr Opin Neurol Neurosurg 6:414-422.

Sheng M, Cummings J, Roldan LA, Jan YN, Jan LY (1994) Changing subunit composition of heteromeric NMDA receptors during development of rat cortex. Nature 368:144-147.

Siegelbaum SA, Kandel ER (1991) Learning-related synaptic plasticity: LTP and LTD. Curr Opin Neurobiol 1:113-120.

Sommer B, Seeburg PH (1992) Glutamate receptor channels: novel properties and new clones. Trends Pharmacol Sci 13:291-296.

Sommer B, Keinänen K, Verdoorn TA, Wisden W, Burnashev N, Herb A, Köhler M, Takagi T, Sakmann B, Seeburg PH (1990) Flip and flop: a cell-specific functional switch in glutamate-operated channels of the CNS. Science 249:1580-1585.

Sommer B, Köhler M, Sprengel R, Seeburg PH (1991) RNA editing in brain controls a determinant of ion flow in glutamate-gated channels. Cell 67:11-19.

Sugihara H, Moryoshi K, Ishii T, Masu M, Nakanishi S (1992) Structures and properties of seven isoforms of the NMDA receptor generated by alternative splicing. Biochem Biophy Res Commun 185: 826-832.

Swope SL, Moss SJ, Blackstone CD, Huganir RL (1992) Phosphorylation of neurotransmitter receptors: a possible mode of synaptic plasticity. FASEB J 6:2514-2523.

Tingley WG, Roche KW, Thompson AK, Huganir RL (1993) Regulation of NMDA receptor phosphorylation by alternative splicing of the C-terminal domain. Nature 364:70-73.

Uhler MD, Carmichael DF, Lee DC, Chrivia JC, Krebs EG, McKnight GS (1986) Isolation of cDNA clones coding for the catalytic subunit of cAMP-dependent protein kinase. Proc Natl Acad Sci USA 83: $1300-1304$.

Wang L-Y, Salter MW, MacDonald JF (1991) Regulation of kainate receptors by cAMP-dependent protein kinase and phosphatases. Science 253:1 132-1135. 
Wang L-Y, Taverna FA, Huang X-P, MacDonald JF, Hampson DR (1993) Phosphorylation and modulation of a kainate receptor (GluR6) by cAMP-dependent protein kinase. Science 259:1173-1175.

Wenthold RJ, Yokotani N, Doi K, Wada K (1992) Immunochemical characterization of the non-NMDA glutamate receptor using subunitspecific antibodies. J Biol Chem 267:501-507.

Wenthold RJ, Trumpy VA, Zhu W-S, Petralia RS (1994) Biochemical and assembly properties of GluR6 and KA2, two members of the kainate receptor family, determined with subunit-specific antibodies. J Biol Chem 269:1332-1339.

Yamazaki M, Araki K, Shibata A, Mishina M (1992) Molecular cloning of a cDNA encoding a novel member of the mouse glutamate receptor channel family. Biochem Biophys Res Commun 183:886892. 